\title{
Interaction effect of nitrogen and potassium on growth and yield of carrot
}

\begin{abstract}
The experiment was carried out to study the effects of three mulching practices viz., no mulch, water hyacinth mulch and polythene mulch, three levels of nitrogen viz., 0, 150 and 200 and three levels of potassium viz., 0,200 and $250 \mathrm{~kg} / \mathrm{ha}$ on the growth and yield of carrot. The yield and yield contributing characters of carrot were significantly influenced by the application of nitrogen and potassium fertilizers with mulching treated plot. The highest marketable yield $(63.47 \mathrm{t} / \mathrm{ha})$ was recorded from the treatment combination of black polythene mulch with $200 \mathrm{~kg} \mathrm{~N} / \mathrm{ha}$ and $200 \mathrm{~kg} \mathrm{~K} / \mathrm{ha}$ treated plot and the lowest $(23.69 \mathrm{t} / \mathrm{ha})$ from the control treatment (MONOK0). But the benefit-cost ratio (BCR) was found maximum (5.60) in the treatment combination of water hyacinth mulch with $200 \mathrm{~kg} \mathrm{~N} / \mathrm{ha}$ and $200 \mathrm{~kg}$ $\mathrm{K} / \mathrm{ha}$, and the lowest (2.54) in control treatment. Considering the above findings, water hyacinth mulch with the application of $200 \mathrm{~kg} \mathrm{~N} / \mathrm{ha}$ and $200 \mathrm{~kg} \mathrm{~K} / \mathrm{ha}$ appeared to be recommendable for carrot cultivation for the place where irrigation facility was not available.
\end{abstract}

Keyword: Carrot; Mulching; Nitrogen; Potassium level 